\title{
MODEL KOMUNIKASI ANTARBUDAYA ETNIK MADURA DAN ETNIK MELAYU
}

\author{
Aminullah $^{1}$, Puji Lestari ${ }^{2}$, dan Sigit Tripambudi ${ }^{2}$ \\ ${ }_{1}^{1}$ T. Multi Prima Entakai, Jl. Semuntai Kabupaten Sangau Kapuas Kalimantan Barat \\ No Telp (0274) 485268, 085251999111, Email: mramincoolz@gmail.com \\ ${ }^{2}$ Program Studi Ilmu Komunikasi, FISIP, Universitas Pembangunan Nasional "Veteran" \\ Yogyakarta, Jl. Babarsari No. 2 Tambakbayan Sleman Yogyakarta, \\ No Telp (0274) 485268, Email : puji.lestari@upnyk.ac.id
}

\begin{abstract}
This study aims to determine the model of intercultural communication and intercultural communication barriers between Madurese and Malays in Roban, Singkawang West Kalimantan. It is research a qualitative research. Data were collected through observation, document review, and interviews. The result shows that the form of communication is mutual respect between cultures and ethnic customs that appreciates each other. Malay ethnic honors and respects customs of Madurese ethnic and vice versa. Inhibiting factors of intercultural communication are less Madurese can mingle with Malay community, lack of knowledge of Madurese ethnic tradition or custom of the Malay ethnic community, lack of desire to follow customs and traditions of local community as well as low frequency of interaction with community.
\end{abstract}

Keywords: ethnic, intercultural communication

Abstrak

Penelitian ini bertujuan menemukan model komunikasi antarbudaya dan hambatan-hambatan komunikasi antarbudaya antara etnik Madura dan Melayu di Roban, Singkawang Kalimatan Barat. Jenis penelitian yang dilakukan adalah penelitian kualitatif, yaitu penelitian yang bersifat memaparkan tentang situasi dan peristiwa, datanya dinyatakan dalam keadaan sewajarnya atau sebagaimana adanya, dengan memaparkan cara kerja yang bersifat sistematik, terarah dan dapat dipertanggung jawabkan, sehingga tidak kehilangan sifat ilmiahnya. Teknik pengumpulan data yang digunakan adalah observasi, kajian dokumen, dan wawancara. Hasil penelitian menunjukkan bahwa model komunikasi antarbudaya Madura dan Melayu yaitu saling menghormati dan menghargai adat kebiasaan antaretnik. Etnik Melayu menghormati dan menghargai adat kebiasaan etnik Madura begitu juga sebaliknya. Sedangkan faktor penghambat dalam komunikasi antarbudaya yaitu masyarakat Madura kurang bisa membaur dengan masyarakat Melayu, kurangnya pengetahuan etnik Madura terhadap tradisi ataupun kebiasaan yang dilakukan masyarakat etnik Melayu, rendahnya keinginan untuk mengikuti adat dan tradisi masyarakat setempat, serta frekuensi interaksi dengan masyarakat tergolong rendah.

Kata kunci: etnis, komunikasi antarbudaya.

\section{Pendahuluan}

Budaya dan masyarakat ibarat dua sisi mata uang logam yang merupakan satu kesatuan yang tidak dapat dipisahkan antara satu sama lain. Budaya tanpa masyarakat itu tidak mungkin, begitu juga sebaliknya masyarakat tanpa budaya itu juga tidak mungkin. Dalam komunikasi antarbudaya, seseorang memiliki budaya yang berbeda dengan orang lain harus bisa mendalami dan mempelajari bagaimana ia berkomunikasi dengan orang yang berbeda budaya. Penelitian komunikasi lintasbudaya sudah banyak diteliti antara lain Riberu, Puji Lestari dan Christina Rochayanti (2015:199) bahwa keanekaragaman yang ada di kota Yogyakarta seperti budaya, perilaku, ras, agama berkumpul menjadi satu kesatuan warga Yogyakarta yang multikultural. Semakin bertambahnya perantau dari luar Yogyakarta atau pun dari luar Jawa semakin menambah keanekaragaman budaya, bahasa, ras, dan agama. Banyak sekali yang datang dan menjadi perantau dari Sabang sampai Marauke, semua berkumpul dan memiliki tujuan masing-masing. Berkomunikasi dengan 
penduduk asli Yogyakarta yang sangat ramah, memiliki kebudayaan daerah yang begitu kental, dan mengedepankan budaya sopan santun.

Komunikasi antarbudaya ini tidak ada saling pengertian antar satu budaya dan lainnya maka pastinya akan terjadi masalah. Dalam ilmu komunikasi antarbudaya, hal utama adalah sumber dan penerimanya berasal dari budaya yang berbeda. Perbedaan kultur dari orang-orang yang berkomunikasi ini juga menyangkut kepercayaan, nilai, serta berperilaku kultur di lingkungan mereka (Fajar, 2009:312).

Perbedaan budaya tidak menjadi halangan untuk satu sama lain menjalin hubungan (relationship), yang terpenting adalahsalingmemahami(understanding), saling beradaptasi (adaptation) dan saling bertoleransi (tolerance). Kunci utama dari pergaulan antarbudaya adalah tidak menilai orang lain yang berbeda budaya dengan menggunakan penilaian budaya sendiri. Biarkan semua berjalan dengan latar budaya masingmasing. Justru perbedaan budaya adalah ladang untuk siapapun belajar budaya orang lain dengan arif dan bijak (wise) (Anugrah dan Kresnowiati, 2007:3). Dalam menjalani kehidupan di dalam masyarakat mengalami banyak-banyak perbedaan, apalagi Indonesia dikenal dengan keanekeragaman budayanya. Dari keanekaragaman inilah tercipta suatu tatanan kehidupan yang unik dan menarik darisetiap kelompokmasyarakat. Ternyata dari keanekaragaman budaya yang seharusnya memperkaya khasanah kehidupan berbudaya, tidak sedikit berawal dari perbedaan ini sering memunculkan kesalahpahaman, ketegangan-ketegangan, antar satu budaya dengan budaya lain. Dalam ingatan ketika pertikaian antar suku yang terjadi di Sambas pada Januari 1999, yang tidak sedikit menelan korban jiwa dan kerugian harta benda. Kerusuhan ini juga meluas sampai ke Roban, Singkawang, Kalimantan Barat (Samovar, 2010:25).

Kehidupan masyarakat Melayu Roban Singkawang bukanlah sifatnya yang suka berperang, maupun memusuhi etnis lain yang ada di daerah Roban Singkawang. Begitu juga dengan Etnis Madura sebagai pendatang sebenarnya sudah sejak lama antara etnis Melayu dengan etnis Madura hidup berdampingan antara satu sama lain, dalam keadaan yang harmonis dan kondusif. Bahkan ada sebagian etnis Madura yang sudah terlahir dan mati di daerah Roban Singkawang dan yang menarik tidak sedikit masyarakat Madura yang ada di daerah Roban, Singkawang sudah tidak mengerti dengan bahasanya sendiri. Itu dikarenakan sudah begitu lama hidup di tengah-tengah masyarakat Melayu Roban Singkawang, serta tidak sedikit dari etnis Madura yang mengikat hubungan batin melalui perkawinan dengan masyarakat Melayu.

Tanpa komunikasi yang baik, komunikasi tatap muka, maupun komunikasi dengan menggunakan media massa penyebaran informasi, terutama informasi kebudayaan akan sulit untuk diperoleh, keadaan seperti ini akan berakibat kurang baik terhadap keranekaragaman budaya yang dimiliki serta akan lebih mempermudah munculnya perselisihan paham karena kekurangpahaman yang akhirnya mengarah kepada konflik. Untuk itu pembahasan komunikasi sangat diperlukan guna kelancaran proses interaksi dengan orang lain. Dalam banyak hal hubungan komunikasi dengan budaya itu bersifat timbal balik, dimana keduanya saling mempengaruhi, dari apa yang dibicarakan, bagaimana membicarakannya dan apa yang dilihat turut membentuk serta menetukan, begitu juga pada gilirannya apa yang dilihat 
dan apa yang dipikirkan itu dipengaruhi oleh budaya yang akhirnya budaya akan hidup tanpa komunikasi dan komunikasi tidak akan hidup tanpa budaya.

Dengan adanya komunikasi yang baik antara satu pihak dengan pihak yang lainnya maka kesamaan arti untuk mencapai suatu tujuan bersama akan mudah tercapai. Keadaan demikianlah yang menunjukkan berhasilnya suatu proses komunikasi yang berlangsung antara kedua belah pihak.

Adapun perumusan masalah dalam penelitian ini berdasarkan latar belakang adalah bagaimana model komunikasi antarbudaya antara etnik Madura dan etnik Melayu di Roban, Singkawang Kalimatan Barat?

\section{Metode Penelitian}

Jenis penelitian yang dilakukan adalah penelitian kualitatif, yaitu penelitian yang bersifat memaparkan tentang situasi dan peristiwa, datanya dinyatakan dalam keadaan sewajarnya atau sebagaimana adanya, dengan memaparkan cara kerja yang bersifat sistematik, terarah dan dapat dipertanggung jawabkan, sehingga tidak kehilangan sifat ilmiahnya (Rakhmat, 1999:23).

\section{Hasil Penelitian dan Pembahasan}

Persepsi Etnik Madura terhadap Etnik Melayu di Kelurahan Roban, Kota Singkawang

Ada sebagian etnis Madura yang masih menaruh curiga terhadap tindakan dan kegiatan yang dilakukan oleh etnis Melayu dalam upaya untuk menggusur etnis Madura dari Kelurahan Roban Singkawang. Sebagian etnis Madura merasa was-was dan berjaga-jaga terhadap segala kemungkinan yang terjadi apabila terjadi konflik lagi yaitu kerusuhan yang melibatkan etnis Madura dan etnis Melayu, sehingga sebagian etnis Madura lebih mempererat hubungan antar etnis Madura sendiri untuk menangkal pengaruh dari etnis Melayu. Etnik Madura berpandangan orang Melayu lemah, penakut dan sebagainya, juga akan mempengaruhi cara komunikasi yang dilakukan. Pada dasarnya, masyarakat etnis Melayu memiliki sifat lembut dan mudah mengalah, namun ketika berhadapan dengan suku Madura yang memiliki tempramen yang begitu keras serta dendam tersendiri yang terakumulasi secara maksimal, maka lama-kelamaan bisa memunculkan sentiment tersendiri yang bertolakbelakang dengan sifat asli masyarakat etnis Melayu.

Dari segi sosial budaya, rumpun Melayu tidaklah terbatas hanya pada suku bangsa Melayu yang ada di Singkawang, atau di Indonesia saja, melainkan juga di beberapa negara di Asia tenggara seperti Malaysia, Singapura, Thailand, Pilipina, Brunei Darussalam dan sebagainya. Sebetulnya ras Melayu merupakan keturunan langsung dari ras pokok dan paling tua di dunia, yakni hasil perpaduan dari ras Mongoloid dengan Kaukasid dan Negroid. Dari ketiga ras ini melahirkan ras Paleomongoloid atau Indomongoloid yang selanjutnya dari perpaduan inilah munculnya ras-ras lain termasuk Melayu yang disebut Proto Melayu dan Deutro Melayu yang ada di Asia dan Indonesia.

Dengan demikian Melayu mempunyai satu rumpun, kendatipun terpisah tempat dan sub kelompoknya. Pendapat ini menurut para ahli sejarah dapat dilihat dari kemiripan peninggalan budayanya seperti kerangka manusia dan binatang, kapak batu dan peninggalan jaman batu yang berasal dari periode sejarah Melayu Mesolitik dan Neolitik.

Masyarakat etnis Melayu selalu memegang prinsip ini dari awal sampai akhir tugas yaitu menghargai, menghormati, memakai adat istiadat di tempat tersebut. Pendapat di atas juga menginformasikan bahwa etnis 
Melayu mempunyai keinginan untuk memegang prinsip budaya masingmasing dan berusaha untuk menghargai, menghormati adat istiadat budaya lain di kelurahan Roban Singkawang. Mayoritas penduduk di kelurahan Roban Singkawang adalah beragama Islam sehingga budaya yang berkembang di sana juga bercorak Islam sehingga etnis Melayu berusaha untuk menghormati budaya Islam yang berkembang di sana dengan menghargai komplek gagasan, konsep dari pikiran dari tokoh masyarakat yang merupakan tokoh masyarakat yang dianggap sebagai wakil dari etnis Melayu. Etnis Melayu juga berusaha untuk menghormati komplek aktivitas yang berupa aktivitasaktivitas yang dilakukan masyarakat di kelurahan Roban Singkawang dalam berinteraksi dalam suatu lingkungan masyarakat. Disamping itu juga etnis Melayu berusaha untuk menjaga bendabenda yang merupakan hasil dari aktivitas masyarakat di Kelurahan Roban Singkawang yang berupa karya-karya yang berbentuk fisik.

\section{Persepsi Etnik Melayu terhadap Etnik Madura}

Persepsi etnik Melayu terhadap etnik Madura yaitu bahwa orang Madura sebagai etnik pendatang dan minoritas di Kalimantan Barat dianggap kurang dapat berasimimilasi atau menyesuaikan diri dengan budaya tradisi masyarakat lokal setempat. Sedangkan, jika dilihat secara mendalam terkait dengan apa yang terjadi di lapangan, data-data menunjukan bahawa kecemburuan sosial yang lahir dari kesenjangan budaya dan sosial telah melahirkan prasangka dan stereotip negatif orang Melayu terhadap orang Madura sebagai kelompok etnis yang ekslusif dan arogan. Ditambah lagi dengan kecemburuan ekonomi yang telah memunculkan prasangka sosial di antara kelompok masyarakat yang terlibat dalam konflik kekerasan. Faktor lain adalah tidak ditegaknya hukum dan keadilan sebagaimana mestinya oleh aparat penegak hukum dalam menangani beberapa kasus kriminal yang melibatkan orang Madura telah melahirkan kecemburuan sosial dan rasa keadilan masyarakat.

Etnik Melayu berpandangan bahwa orang Madura keras, bertemparamen tinggi, mudah marah dan sebagainya akan berpengaruh pada bentuk komunikasi yang akan dibangun dengan orang madura tersebut. Warga Madura di Kelurahan Roban Kabupaten Singkawang dianggap terlalu gampang menyelesaikan selisih paham dengan menggunakan senjata tajam. Warga Madura membawa senjata tajam untuk menjaga diri dan bila perlu untuk membela kehormatan. Tetapi, itulah yang dipandang mendorong mudahnya warga Madura melakukan tindak kekerasan.

\section{Faktor Penghambat}

Gangguanyang menjadi penghambat dalam proses komunikasi antarbudaya etnis Melayu dan etnis Madura yaitu masyarakat Madura sebagai masyarakat pendatang di Kelurahan Roban Singkawang sejauh ini dalam pergaulan sehari-hari dengan masyarakat pribumi yaitu masyarakat Madura kurang bisa membaur dengan masyarakat setempat walaupun tidak semua suku Madura yang ada di kelurahan Roban Singkawang demikian, ini dikarenakan rasa kesukuan yang terlalu tinggi sehingga hal tersebut berpengaruh kurang baik terhadap berlangsungnya aktifitas komunikasi antar dua masyarakat yang berlatar belakang kebudayaan yang berbeda selain itu kurang bisa membaurnya orang-orang suku Madura dengan masyarakat pribumi disebabkan bisa menyesuaikan dengan lingkungan yang ada di sekitarnya mereka cenderung membuat perkumpulan sendiri khusus 


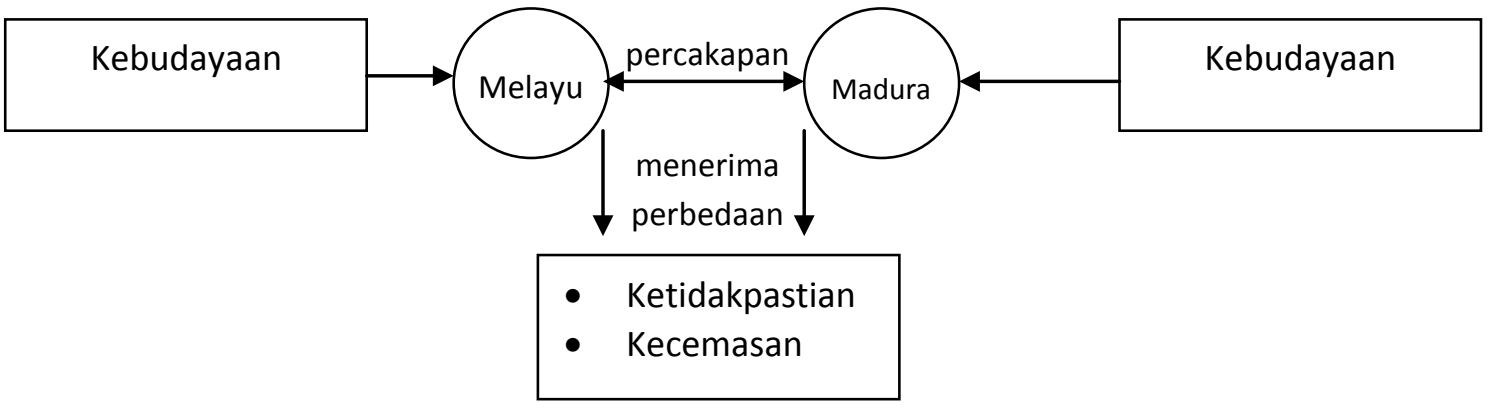

\section{Gambar 1. Model Komunikasi Antarbudaya Melayu dan Madura}

untuk orang-orang Madura sehingga membuat terhambatnya komunikasi yang baik diantara yang baik.

Hasil penelitian menunjukkan sebagian informan terutama informan etnis Madura sangat sering mengalami hambatan, ditandai dengan kurangnya pengetahuan etnis Madura terhadap tradisi ataupun kebiasaan yang dilakukan masyarakat etnis Melayu, kurang mampu menguasai bahasa etnis, ren-dahnya keinginan untuk mengikuti adat dan tradisi masyarakat setempat, serta frekuensi interaksi dengan masyarakat tergolong rendah. Hal tersebut mempengaruhi sikap dan perilaku antara etnis Madura dengan masyarakat etnis Melayu. Hal tersebut tidak menimbulkan konflik terhadap suku bangsa yang berbeda. Dari data-data yang dikumpulkan melalui observasi langsung dan wawancara secara mendalam terhadap informan, terlihat bahwa masing-masing informan etnis Madura dan masyarakat etnis Melayu memiliki tingkat sikap dan perilaku yang berbeda-beda. Belum ada wadah yang kondusif untuk melakukan komunikasi yang intens antara kedua etnis tersebut sehingga dapat mengurangi kecurigaan diantara etnis yang ada di kelurahan Roban Singkawang. Etnis Melayu dan Madura juga menyadari bahwa dengan sering berdiskusi akan mempererat hubungan diantara mereka sehingga dapat mencegah konflik antar etnis yang dapat mengarah kepada perpecahan antar etnis.

Etnis Madura tetap belum sepenuhnya menerima pujian yang disampaikan etnis Melayu. Etnis Madura pada umumnya lebih bersikap curiga dan siaga terhadap segala pujian yang disampaikan oleh etnis Melayu. Etnis Madura terlebih dahulu menyelidiki bentuk dari pujian yang disampaikan, dan membahas dengan kelompoknya, sehingga dapat disimpulkan, apakah pujian itu ada motif tertentu dan terselubung ataukah pujian tersebut bersifat objektif. Apabila dirasa pujian itu terdapat motif terselubung maka etnis Madura akan mengambil sikap waspada dan menjaga jarak dengan etnis Melayu. Hal ini akan mengakibatkan hubungan antar etnis menjadi longgar dan rawan terjadi konflik. Namun apabila pujian tersebut bersifat objektif maka etnis Madura akan menerimanya dengan senang dan mengucapkan terima kasih. Akan tetapi etnis Madura terlebih dahulu merasa curiga terhadap pujian ini sehingga sebagian besar pujian yang disampaikan oleh etnis Melayu terhadap etnis Madura selalu dicurigai terlebih dahulu sebelum memutuskan untuk mengambil tindakan terhadap pujian tersebut.

Keanekaragaman budaya yang ada di Kelurahan Roban Singkawang mengakibatkan terjadinya komunikasi antarbudaya, salah satunya adalah 
komunikasi antarbudaya etnis Melayu dengan etnis Madura. Etnis Melayu berperan sebagai komunikator yang menyampaikan pesan yang berupa pikiran, ide atau gagasan kepada komunikan (etnis Madura) yang tinggal di Kelurahan Roban Singkawang.

Berdasarkan observasi dan wawancara terhadap kedua suku bangsa yang berbeda ini peneliti melihat adanya keterkaitan antara integrasi sikap dan perilaku budaya dengan variabelvariabel, seperti lamanya menetap di suatu daerah, pola pemukiman, jenis pekerjaan, dan frekuensi interaksi dengan ingroup maupun outgroup-nya.

\section{Etnis Madura}

Sulit memang memastikan kapan awal mula kedatangan etnis Madura di Singkawang, tapi dari berbagai catatan sejarah dipastikan bahwa jauh sebelum kemerdekaan, suku Madura sudah tiba dan berada di bumi khatulistiwa. Sejarah mencatat bahwa kedatangan etnis Madura di Singkawang ini dengan naik perahu layar tradisional. Kedatangan etnis Madura semula adalah berdagang sapi, sebagian yang lain mencari pekerjaan. Untuk kedatangan semula di dua pelabuhan utama yaitu Pelabuhan Sepulu dan Pelabuhan Telaga Biru Tanjung Bumi Bangkalan. Semakin hari semakin meningkat jumlah warga Madura di Singkawang terutama menjelang tahun 1980 hingga 1990. Pada saat itu hampir setiap pelayaran ke Singkawang membawa warga Madura hingga 50-an orang. Pelayaran tersebut sebenarnya merupakan kapal dagang dan bisnis. Dari Madura membawa sapi dan hasil bumi khas Madura seperti jagung, garam, ketela, atau mangga. Dari Kalbar suku Maudura membawa hasil hutan seperti kayu. Begitulah seterusnya hingga ribuan orang Madura datang dan menetap di Singkawang.
Tabel 1. Tingkat Pendidikan Responden

\begin{tabular}{llcc}
\hline No & $\begin{array}{c}\text { Tingkat Pendidikan } \\
\text { Warga Binaan }\end{array}$ & Frekuensi & $\begin{array}{c}\text { Prosen- } \\
\text { tase }\end{array}$ \\
\hline 1. & Tidak Sekolah & 1 & $0.6 \%$ \\
2. & Sekolah Dasar & 16 & $7.8 \%$ \\
3. & SMP & 31 & $15 \%$ \\
4. & SMA/STM/Aliyah & 87 & $42 \%$ \\
5. & Diploma Tiga & 7 & $3.5 \%$ \\
6. & Sarjana & 7 & $3.5 \%$ \\
7. & Tidak & 57 & $27.6 \%$ \\
& terindentifikasi & $\mathbf{2 0 6}$ & $\mathbf{1 0 0}$ \\
\hline
\end{tabular}

\section{Etnis Melayu}

Media yang digunakan oleh etnis Melayu dan etnis Madura dalam berkomunikasi antarbudaya adalah percakapan tatap muka yaitu dengan saling berdialog dan bertukar pendapat di dalam acara perayaan hari besar keagamaan yang diselenggarakan oleh etnis Melayu maupun oleh etnis Madura.

Efek atau umpan balik dengan adanya komunikasi antarbudaya etnis Melayu dan etnis Madura di Kelurahan Roban Singkawang adalah integrasi sikap dan perilaku budaya terlihat dari kesediaan beberapa informan menyesuaikan diri dengan sukusuku yang ada di lingkungannya, misalnya dengan mempelajari bahasa, membiasakan diri dengan masakan dari ingroup maupun outgroup, mengadopsi nilai-nilai budaya dari suku-suku setempat. Hal ini juga mengisyaratkan bahwa antara etnis Melayu dan etnis Madura terdapat rasa saling tenggang rasa dengan tidak memperbesar perbedaan tetapi berusaha untuk menyelesaikan setiap permasalahan dengan pertemuan atau dialog. Etnis Madura mempunyai itikad untuk berusaha membangun dialog dengan etnis Melayu apabila ada perbedaan pendapat, dengan jalan melakukan pertemuan dan diskusidengan tokoh-tokoh masyarakat yang mewakili etnis Melayu untuk menyelesaikan segala permasalahan dengan cara musyawarah untuk mufakat. Baik etnis Melayu dan etnis Madura sama-sama 
Tabel 2. Tingkatan Usia Responden

\begin{tabular}{llcc}
\hline No & $\begin{array}{c}\text { Usia Warga } \\
\text { binaan }\end{array}$ & Frekuensi & Prosentase \\
\hline 1. & $\begin{array}{l}\text { Di bawah } 20 \\
\text { tahun }\end{array}$ & 4 & $1.9 \%$ \\
2. & 20 th. -25 th. & 54 & $26.2 \%$ \\
3. & 26 th. -30 th. & 53 & $25.7 \%$ \\
4. & 31 th. -35 th. & 45 & $22 \%$ \\
5. & 36 th. -40 th. & 25 & $12.1 \%$ \\
6. & Di atas 40 th. & 25 & $12 \%$ \\
& Jumlah & $\mathbf{2 0 6}$ & $\mathbf{1 0 0}$ \\
\hline
\end{tabular}

menghindari kekerasan apabila terjadi suatu masalah dalam hubungan antar etnis. Hal ini juga menunjukkan bahwa sebenarnya etnis Melayu dan Madura tidak suka permusuhan dan kekerasan apabila terjadi beda pendapat antar etnis. Keduanya berusaha untuk menempuh jalan perdamaian dengan jalan mencari titik temu apa yang menjadi masalah dan berusaha untuk menyelesaikan permasalahan itu dengan jalan damai yaitu dengan melakukan dialog dan pertemuan dengan tokoh masing-masing.

Berdasarkan uraian di atas diketahui bahwa usaha yang dilakukan yaitu membicarakan apa yang menjadi permasalahan tersebut, setelah mendapatkan solusi, tokoh masyarakat menyampaikan kepada masing masing sukunya. Etnis Melayu dan Madura mengadakan pertemuan yang intinya membicarakan dan membahas apa yang menjadi masalah yang terjadi diantara hubungan budaya diantara keduanya. Pertemuan tersebut dihadiri oleh tokohtokoh masyarakat dari etnis masingmasing yang berdiskusi dengan tidak saling menyalahkan diantara keduanya. Tokoh-tokoh tersebut berupaya untuk menemukan akar permasalahan atau sengketa yang terjadi dengan mengedepankan musyawarah untuk mufakat dan tidak saling menyalahkan. Setelah terjadi kesepakatan diantara tokoh-tokoh masyarakat yang berkumpul dan berdiskusi tersebut, maka hasil dari pertemuan tersebut disampaikan kepada kelompok-kelompok atau etnis masingmasing.

Suasana yang meliputi tempat dan waktu yang digunakan oleh etnis Melayu dan etnis Madura dalam berkomunikasi antarbudaya adalah di gedung pertemuan atau di rumah salah satu tokoh masyarakat pada saat perayaan hari besar keagamaan umat Islam. Di dalam perayaan etnis Melayu mengundang etnis Madura untuk ikut bersama merayakan hari besar Islam yang sudah menjadi adat istiadat masyarakat di Kelurahan Roban Singkawang. Etnis Madura juga sering diundang untuk menghadiri acara-acara keagamaan yang dilaksanakan oleh etnis Melayu seperti Idul Fitri, Idul Adha dan Maulid Nabi Muhammad SAW.

Organisasi masyarakat dari etnis Madura berusaha untuk membangun silaturahmi dengan etnis Melayu dengan cara mengikuti dan mendatangi undangan kegiatan keagamaan yang dilakukan oleh etnis Melayu diantaranya yaitu peringatan Isra' Mi'raj Nabi Muhammad SAW. Tokoh masyarakat dari etnis Madura berusaha untuk menghormati undangan yang disampaikan oleh etnis Melayu dengan cara mendatangi setiap kegiatan keagamaan yang diadakan di kelurahan Roban Singkawang, begitu juga sebaliknya apabila etnis Madura mengadakan upacara atau kegiatan keagamaan, mereka juga mengundang tokoh-tokoh etnis Melayu untuk ikut serta dalam kegiatan tersebut. Diantara kedua etnis tersebut berusaha untuk mencari kesamaan yaitu beragama Islam dan menjalankan perintah sesuai dengan ajaran Islam, sehingga dengan adaya kesamaan tersebut diharapkan akan tercipta rasa persaudaraan diantara keduanya. Di dalam ajaran Islam juga disebutkan bahwa sesama muslim adalah saudara sehingga tokoh-tokoh masyarakat etnis Madura dan Melayu berusaha untuk menyatukan etnis 
tersebut karena pada dasarnya mereka adalah saudara.

Berdasarkan hasil wawancara terungkap bahwa ada sebagian etnis Madura yang masih menaruh curiga terhadap tindakan dan kegiatan yang dilakukan oleh etnis Melayu dalam upaya untuk menggusur etnis Madura dari Kelurahan Roban Singkawang. Etnik Madura berpandangan orang Melayu lemah, penakut dan sebagainya, juga akan mempengaruhi cara komunikasi yang dilakukan. Pada dasarnya, masyarakat etnis Melayu memiliki sifat lembut dan mudah mengalah. Kenyataan ini memperkuat teori stereotip yang menyatakan bahwa stereotip merupakan bentuk kompleks dari pengelompokan yang secara mental mengatur pengalaman dan mengarahkan sikap dalam menghadapi orang-orang tertentu. Hal ini menjadi cara untuk mengatur gambaran-gambaran yang dimiliki ke dalam suatu kategori yang pasti dan sederhana yang digunakan untuk mewakili sekelompok orang. Hal yang sama juga terjadi di etnis Melayu yang mempunyai persepsi terhadap etnik Madura yaitu bahwa orang Madura sebagai etnik pendatang dan minoritas di Kalimantan Barat dianggap kurang dapat berasimimilasi atau menyesuaikan diri dengan budaya tradisi masyarakat lokal setempat. Hal ini menimbulkan kesan bahwa etnis Madura menganut budaya individualisme yaitu masyarakat memandang dan menjaga diri pribadi dan keluarganya, sedangkan di dalam budaya kolektivisme, masyarakat adalah milik bersama dan diarahkan untuk saling menjaga loyalitas kelompok. Budaya ini berkembang di etnis Madura yang bertujuan untuk melayani kebutuhan vital dan praktisi etnis Madura untuk membentuk masyarakat juga untuk memelihara spesies, menurunkan pengetahuan dan pengalaman berharga ke generasi berikutnya, menghemat biaya dan bahaya dari proses pembelajaran.

Budaya menentukan dan membentuk perilaku, nilai dan bahkan pikiran suatu kelompok masyarakat. Hal ini juga berlaku di dalam etnis Madura dan etnis Melayu. Masing-masing etnis masih memiliki rasa primordialisme masing-masing kelompok budaya terhadap budayanya. Untuk beradaptasi terhadap suatu budaya tertentu bukanlah merupakan suatu pekerjaan yang mudah, karena budaya dibekalkan kepada manusia dilahirkan ke dunia yang tentunya melalui proses pembelajaran oleh tempat tinggal yang mempunyai sifat dan ciri-ciri tersendiri. Sehingga apabila seseorang pergi ke suatu daerah yang memiliki budaya yang berbeda dengan tempat asalnya, maka mau tidak mau harus berusaha untuk beradaptasi dengan memahami budaya di lokasi yang baru tersebut.

Hasil penelitian juga memperkuat teori etnosentrisme yang menjelaskan etnosentrisme merupakan pandangan bahwa budaya seseorang lebih unggul dibandingkan budaya yang lain. Pandangan bahwa budaya lain dinilai berdasarkan standar budaya kita. Kita menjadi etnosentris ketika kita melihat budaya lain melalui kacamata budaya kita atau sosial kita. Kebanyakan orang merupakan etnosentris dan bahwa kadang sifat etnosentrisme penting untuk mengeratkan hubungan dalam suatu masyarakat. Seperti budaya, etnosentrisme juga biasanya dipelajari secara tidak sadar. Misalnya, sekolah yang hanya mengajarkan sejarah, geografi, sastra, bahasa, serta pemerintahan negara sendiri dan mengecualikan yang lainnya sedang melakukan tindakan etnosentrisme. Hal ini juga berlaku di etnis Melayu dan etnis Madura yang tinggal di Roban Singkawang yang beranggapan bahwa etnis masing-masing lebih unggul dibandingkan etnis yang lain. 
Komunikasi antarbudaya yang melibatkan etnis Melayu dan etnis Madura tidak bisa terlepas dari hakikat proses komunikasi antarbudaya yang menyatakan bahwa komunikasi ini tidak bisa dipandang sekedar sebagai sebuah kegiatan yang menghubungkan manusia dalam keadaan pasif, tetapi komunikasi harus dipandang sebagai proses yang menghubungkan manusia melalui sekumpulan tindakan yang terus menerus diperbaharui. Hal ini sesuai dengan hasil observasi yang tah dilakukan peneliti di lokasi penelitian yang menemukan fakta bahwa komunikasi antarbudaya etnis Melayu dan etnis Madura merupakan proses yang menghubungkan manusia melalui sekumpulan tindakan yang terus menerus diperbaharui. Hal ini senada dengan penelitian Suryani, Wahidah (2013:12) Kemajuan teknologi komunikasi dan transportasi memungkinkan terjadimya komunikasi antarbudaya. Berkaitan dengan hal tersebut, sangat mendesak bagi setiap orang untuk mengenal dan memahami budaya orang lain di luar dirinya. Mencoba menghilangkan atau meminimalisir bias komunikasi yang mungkin terjadi. Salah satu langkah konkrit adalah membangun penghubung antarbudaya.

Proses komunikasi antarbudaya antara etnis Melayu dan etnis Madura di Roban Kalimantan Barat mencakup unsur-unsur komunikasi antarbudaya sesuai dengan pendapat dari Liliweri (2007:25-32) yaitu: komunikator, komunikan, pesan/simbol, media, efek atau umpan balik, suasana, dan gangguan. Unsur-unsur ini saling berhubungan satu dengan yang lain dalam proses komunikasi antarbudaya di Roban Kalimantan Barat.

\section{Simpulan}

Berdasarkan hasil penelitian yang telah dilakukan, maka dapat diambil kesimpulan bahwa komunikasi antarbudaya antara etnik Melayu dan etnik Madura di Roban Kalimantan Barat adalah dengan menyelesaikan masalah dengan cara diskusi antara tokoh-tokoh yang mewakili dari etnik masing-masing. Setelah melakukan diskusi tersebut, maka tokoh dari masing-masing etnik akan menyampaikan hasil diskusi tersebut kepada kelompoknya masing-masing.

Bentuk komunikasi lain yaitu saling menghormati dan menghargai adat kebiasaan etnik masing-masing. Etnik Melayu menghormati dan menghargai adat kebiasaan etnik Madura begitu juga sebaliknya.

Saling mengundang antara etnik Melayu dan etnik Madura dalam merayakan hari besar keagamaan. Apabila etnik Melayu mengadakan suatu perayaan hari besar keagamaan, maka akan mengundang etnik Madura untuk menghadiri dan ikut berpartisipasi, begitu juga sebaliknya apabila etnik Madura merayakan hari besar keagamaan juga akan mengundang pihak etnik Melayu

Ada sebagian dari etnik Madura dan etnik Melayu yang merasa tidak adanya kepastian dalam melakukan komunikasi antarbudaya tersebut dan bahkan ada yang merasakan kecemasan akan keselamatan diri dan anggota keluarga setelah melakukan komunikasi antar budaya dengan etnik lain di Kelurahan Roban Singkawang Kalimantan Barat.

Faktor penghambat dalam komunikasi antarbudaya antara etnik Melayu dan etnik Madura di Roban Kalimantan Barat adalah masyarakat Madura kurang bisa membaur dengan masyarakat Melayu. Kurangnya pengetahuan etnik Madura terhadap tradisi ataupun kebiasaan yang dilakukan masyarakat etnik Melayu, etnik Madura kurang mampu menguasai bahasa etnik Melayu, rendahnya keinginan etnik Madura untuk mengikuti adat dan tradisi masyarakat etnik Melayu, serta frekuensi interaksi etnik Madura dengan masyarakat etnik Melayu tergolong rendah. 
Implikasi hasil penelitian ini adalah bahwa komunikasi antar etnis sangat diperlukan untuk mengurangi konflik komunikasi. Komunikator harus mengerti karakteristik etnik komunikan dan sebaliknya. Tujuan komunikasi antar etnik untuk meningkatkan keharmonisan antar etnik.

\section{Daftar Pustaka}

Anugrah, Danang \& Winny Kresnowiati. (2007). Komunikasi Antarbudaya: Konsep dan Aplikasinya. Jakarta: Jala Permata.

Fajar, Marhaeni. (2009). Ilmu Komunikasi Teori \& Praktek. Yogyakarta: Graha Ilmu.

Liliweri, Alo. (2007) Dasar-Dasar Komunikasi Antarbudaya. Yogyakarta: Pustaka Pelajar Offset.

Rakhmat, Jalaludin. (1999) Psikologi Komunikasi. Bandung: PT. Remaja Rusdakarya.
Samovar, Larry A, Porter, Richad E, Mcdaniel, Edwin R. (2010) Komunikasi Lintas Budaya. Jakarta: Salemba Hunanika.

\section{Jurnal Ilmiah:}

Ruberu, Yohanes, Puji Lestari \& Christina Rochayanti. (2015). Model Komunikasi Antarbudaya Mahasiswa Nusa Tenggara Timur Dengan Penduduk Tambak Bayan Yogyakarta Pasca Peristiwa Cebongan, Jurnal Ilmu Komunikasi Avant Garde, Volume 3 No.2 Desember 2015. Jakarta: Universitas Budi Luhur.

Suryani, Wahidah. (2013). Komunikasi Antarbudaya: Berbagi Budaya Berbagi Makna. Jurnal Farabi Vol. 10 No. 1 Juni 2013, Gorontalo: Fakultas Ushusuddin \& Dakwah Institut Agama Islam Negeri (IAIN) Sultan Amai Gorontalo. 